\title{
TEACHERS’ OCCUPATIONAL WORK ETHIC SCALE IN SOUTH KOREA
}

\author{
HwaChoon Park \\ Korea Research Institute for Vocational Education and Training (South Korea)
}

\begin{abstract}
The Teachers' Occupational Work Ethic Scale (TOWES) was developed to provide schools with psychometrically sound teacher survey for assessing work ethic. Based on an extensive literature review on work ethic instruments and interviews of 16 principals from K-12 schools, initial survey questions were developed. A series of content and face validity of the initial items were examined by panels of judging experts. A total of 500 teachers across K-12 schools in South Korea provided usable data. Exploratory and confirmatory factor analyses verified the scale's structure and suggested a four-factor model: Work Ethic in Instruction, Work Ethic toward Students, Work Ethic in Overall Performance at School, and Work Ethic toward Fellow Teachers. The factor structure was shown to be stable across school levels (i.e., elementary, middle, and high school) and gender. Additional support for the construct validity of the TOWES was obtained based on scores of each of the four factors correlated moderately, across groups and at the school level, with job satisfaction and Teachers' Vocational Ethics. Implications and suggestions for further research and practice are discussed.
\end{abstract}

Keywords: Work ethic, teachers' work ethic, scale development, factor analyses.

\section{Introduction}

Education is a foundational driving power not only for students' development but also for a nation. The contemporary society accounts schools and teachers more and more for student learning and expects teachers to model behaviors reflective of moral virtues like honesty and fairness (Lumpkin, 2008). The public expects teachers to perform according to professional codes of conduct (Lumpkin, 2008). Teachers are often put into educational contexts to cope with questions of what is right and what is good (Paolitto, 1977) and continually face moral dilemmas surrounding issues such as treating and guiding students, telling the truth, and keeping promises. Teachers are considered moral philosophers (Paolitto, 1977). Jobs of teachers are viewed as professions which require high moral stature (Hill, workethicsite) in that teachers greatly influence the lives of students who experience special development stages as human beings (Lumpkin, 2008). Students not only acquire knowledge and skills but also have opportunities for their character development through social interactions with teachers, and thus teachers are to serve as role models of character by making professional decisions and judgements based on societal and moral virtues (Lumpkin, 2008). Korea is not an exception. The contemporary Korean teachers tend to perceive their roles as a "service representative, customer consultant, care worker, academy teacher, and sometimes, civil affairs official (Kweon \& Kim, 2015, p. 108).” However, ethically wrong behaviors of some teachers such as leaking of exam questions, sexual abuse, unfair grading, authority abuse, and inappropriate punishment have been continually issued in Korean school settings.

\section{Objectives}

Thus, the purpose of this study was to develop a scale to assess teachers' occupational work ethic for K-12 school teachers in South Korea. This study was guided by the following research questions.

RQ1: What constructs comprise the occupational work ethic of Koreans teachers in K-12 schools as measured by the Teachers' Occupational Work Ethic Scale?

RQ2: What is the work ethic of Koreans teachers as measured by the TOWES?

RQ3: Do differences exist in the work ethic for women and men and for school levels? 


\section{Methods}

The main purpose of the present study is to create a scale to measure teachers' occupational work ethic in Korea. To conduct this study, the IRB was first approved by the institute that the first author is affiliated. In order to develop the measure, existing literature on work ethic, work ethic instruments, characteristics of desirable teachers was examined to determine potential factors that are considered part of the teachers' occupational work ethic. In addition, 16 principals in K-12 public schools were interviewed to reflect the contemporary views on teachers' occupational work ethic. Based on the literature review and interviews of principals, four domains were identified: work ethic in instruction, work ethic toward students, work ethic in overall performance, and work ethic toward fellow teachers.

Next, items were developed by the first author to tap into these constructs. Specifically, work ethic measures developed by Park and Hill (2016), Mann, Taber, and Haywood (2013), and Miller, Woehr, and Hudspeth (2002) were mainly considered for the general work ethic. For the factors of teachers' work ethic were based on studies by Lumpkin (2008), Markert (2004), Turk and Vignjević (2016), and Paolitto (1977). A total of 153 items were collected and developed at this stage. Based on the conceptual factors, open-ended questions were developed to interview principals in K-12 schools. Examples of interview questions include 'Define work ethic and teachers' work ethic on your own', 'What characteristics do represent teachers' occupational work ethic', 'If you have met or seen a teacher who had or has a strong work ethic as a teacher, describe the teacher's behaviors or words that impress you.' From one hour to one and a half hours were spend in interviewing each principal.

\subsection{Sample}

A total of 393 K-12 school teachers in South Korea participated in the survey. The data file was randomly split into two subsamples for the purposes of conducting exploratory and confirmatory factor analyses to examine the structure of the TOWES (Tabachnick \& Fidell, 2007). For all other purposes of this study, the entire file was used.

\subsection{Materials}

Teachers Occupational Work Ethic Scale. All participants in the present study completed the newly developed Teachers Occupational Work Ethic Scale (TOWES). The TOWES is a 77-item self-report scale that measures the four dimensions of teachers' work ethic: work ethic in instruction, work ethic toward students and parents, work ethic in overall performance at school, and work ethic toward fellow teachers and school staff. All items are rated on a 7-point Likert scale (1=Strongly Disagree to 7=Strongly Agree). Example items include "I do not waste class time.", "When grading students' outcomes, I am fair." The second domain of the TOWES is to measure teachers' ethical behaviors toward students and parents. Sample items include "I treat each student with respect." "I care about students." "I listen to each student when he or she has a problem." The fourth domain of the TOWES is designed to assess teachers' overall ethical behaviors at school and in the society. Example items include "I follow school policy and rules." "I make my efforts to model before students and fellow teachers." The last domain of the TOWES is to measure teachers' ethical behaviors toward their fellow teachers and school staff. Sample items include "I treat fellow teachers fairly." "I listen to each fellow teacher and staff even though his or her opinion is different from mine." Work ethics (or employability skills) were measured by the occupational work ethic inventory-short form (OWEI-SF) (Park \& Hill, 2018), which is designed for students, trainees, or adults to assess their own work ethic in a relatively short time and in combination with other instruments (Park \& Hill, 2018). The OWEI-SF consists of 12 items and has three subscales; interpersonal skills, initiative, and being dependable based on a seven-point Likert scale for rating each item with 1 (never); 2 (almost never); 3 (seldom); 4 (sometimes); 5 (usually); 6 (almost always); and 7 (always). The first factor, interpersonal skills, has four items (e.g., friendly), the second factor, initiative, includes five items (e.g., ambitious), and the third factor, dependability, has three items (e.g., following directions). Reliabilities of each subscale were .83 for interpersonal skills, $=.75$ for initiative, and $=.76$ for being dependable, respectively (Park \& Hill, 2018). The model indices of the results of confirmatory factor analysis model of the OWEI-SF: $\chi^{2}(\mathrm{df})=889.161(54), \mathrm{CFI}=.902$, $\mathrm{SRMR}=.045$, and the overall Cronbach's alpha was .910 .

\subsection{Data analysis}

To establish the TOWE scale construction, several subsequent statistical analyses were involved: (1) exploratory factor analysis to identify the desirable common factor model of the TOWES, (2) confirmatory factor analysis to examine the stability of the derived factor model, and (3) examination of the internal consistency of the TOWES (Crocker \& Algina, 1986). 


\section{Findings}

Principal component analysis was performed on the first sample $(n=226)$ to examine the underlying structure of the 77 items of the TOWES. Next, principal axis factoring was used to derive a common factor model. A number of PCAs and PAFs were repeated to find a best common factor model. Based on the criteria set up for selecting items, a six-factor model with 29 items was finally selected. Factor loadings of each item, eigenvalues of the six factors, and the common variance explained are presented (see Table 1).

Table 1. Factors of the TOWES and Loadings.

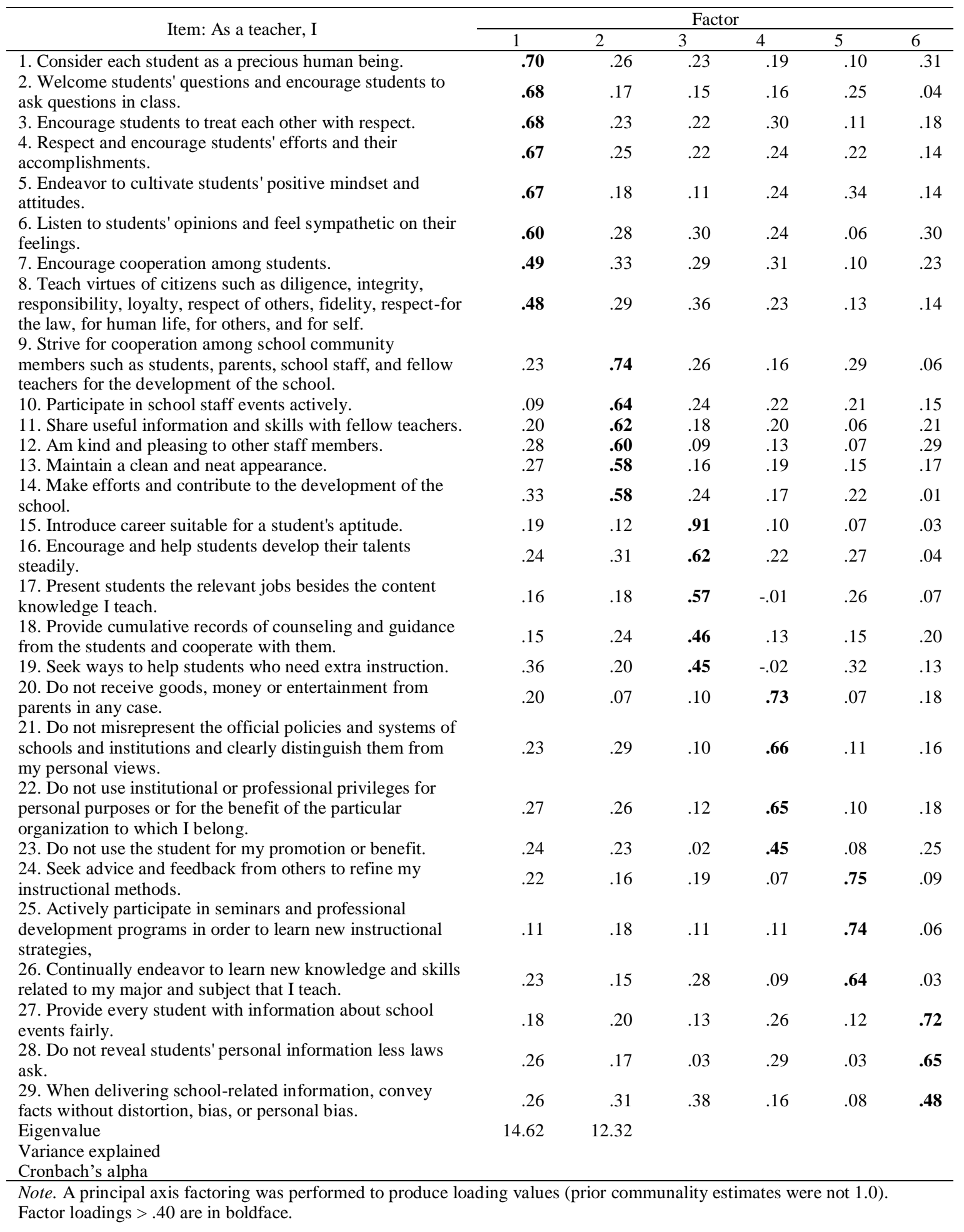


The first factor includes eight items with loading values ranged from .70 to .48 and named respect of students, which reflects teachers' attitudes towards students. Factor 2 includes six items with loading values ranged from .74 to .58 and was labeled as active engagement in school activities, which represents active participation in school events, cooperative projects, and overall maintenance as a teacher. The third factor consists of five items with loading values ranged from .91 to .45. This factor was named meaningful caring of students. Factor 4 consists of four items and their loading values ranges from .73 to .45 . It was labeled as following school rules and laws, which reflects teachers' integrity to keep laws, rules, and principles. Factor five includes three items with loading values from .75 to .64, which reflects taking initiatives to become more professionally developed. It was labeled as initiatives. The last factor consists of three items and reflects fair job performance such as providing information fairly. It was labeled as fairness. Next, CFA with the proposed six-common-factor model of the TOWEI was conducted. Selected modeling information indices were RMSEA $=0.068 ; 90 \%$ CI [.059, .064], p-value $<.0001 ; \mathrm{CFI}=.92, \mathrm{SRMR}=0.04$, and TLI $=.91$. Finally, the internal consistency was examined, using Cronbach's alpha: for $\mathrm{f} 1, \alpha=.93$; for $\mathrm{f} 2, \alpha=.88$; for $\mathrm{f} 3, \alpha=.84$; for $\mathrm{f} 4, \alpha=.82$; for $\mathrm{f} 5, \alpha=.77$; and for f6, $\alpha=.79$.

\section{Conclusions and discussion}

This article presents a measurement instrument to assess Korean teachers' individual occupational work ethic. The results of a series of EFA and CFA suggested a six-common-factor model of the TOWES and model indices produced satisfied the statistical criteria of a good model fit to the data collected. This research study can provide policy makers and program developers for pre-service and in-service teachers for their own professional development.

\section{Acknowledgements}

This work was supported by a National Research Foundation of Korea grant funded by the Korean Government (2018S1A5A8029526).

\section{References}

Crocker, L. M., \& Algina, J. (1986). Introduction to classical and modern test theory. New York, NY: Holt, Rinehart, and Winston.

Kweon, M. K., \& Kim, C. G. (2015). The parents' attitude of consumer sovereignty and the subsequent teachers' withdrawal with identity change as the point of view of teachers. The Journal of Educational Research, 13(3), 83-109.

Lumpkin, A. (2008). Teachers as role models teaching character and moral virtues. Journal of Physical Education, Recreation and Dance, 79(2), 45-50. doi:10.1080/07303084.2008.10598134

Mann, M. J., Taber, T. D., \& Haywood, K. J. (2013). Work ethic revisited: Identifying and operationalizing new dimensions of work ethic a century after Weber. Journal of Business Disciplines, 11(1), 65-101.

Markert, L. R. (2004). Ethics in a culturally diverse technological world. In R. B. Hill (Ed.), Ethics for citizenship in a technological world: 53rd yearbook (pp. 21-48), Council on Technology Teacher Education, New York, NY: Glencoe McGraw-Hill.

Miller, M. J., Woehr, D. J., \& Hudspeth, N. (2002). The meaning and measurement of work ethic: Construction and initial validation of a multidimensional inventory. Journal of Vocational Behavior, 59, 1-39. doi:10.1006/jvbe.2001.1838

Paolitto, D. P. (1977). The role of the teacher in moral education. Theory into Practice, 16(2), 73-80.

Park, H. \& Hill, R. B. (2016. 12. 1). The employability skills assessment: Measuring work ethic for research and learning. Career and Technical Education Research, 41(3),175-192. doi:10.5328/cter41.3.175.

Park, H. \& Hill, R. B. (2018. 1. 3). Development and validation of a short form of the occupational work ethic inventory. Journal of Career and Technical Education, 32(1), 9-28.doi:10.21061/jcte.v32i1.1588.

Tabachnick, B. G., \& Fidell, L. S. (2007). Using multivariate statistics. Boston: Pearson/Allyn and Bacon. 